\title{
YALE
}

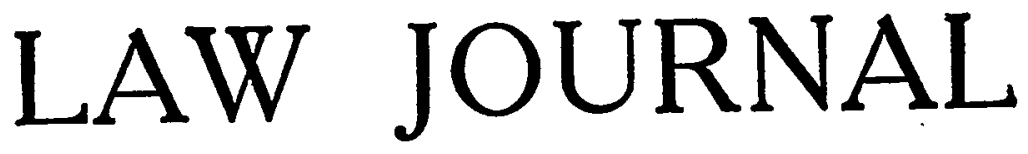

\begin{tabular}{lll}
\hline \hline Vol. XXVII & JANUARY, 1918 & No. 3 \\
\hline
\end{tabular}

\section{INTER-CITIZENSHIP: A BASIS FOR WORLD PEACE ${ }^{1}$}

\author{
ORRIN K. MCMURRAY \\ Professor of Law, University of California
}

In the early Roman State to be a Roman and to possess rights were synonymous terms, and what is true of Rome was equally characteristic of the ancient city state in general. The word civis, the root from which are derived both "citizen" and "civilization," meant a member of the city, and it was one's connection with the city that gave him rights. He who was not a civis was in the early Roman law regarded as destitute of legal rights.

"Citizens alone are entitled to the protection of the laws. An alien is an outlaw, no less destitute of all legal rights and remedies than if he were a slave. He can own no property, can make no contract, nor any claim in a court of justice, can enter into no valid marriage, nor have any lawful issue. He is an enemy of the Roman State and at the mercy of any of its members. In practice he may enjoy some measure of precarious security by placing himself under the protection of some Roman citizen, who as his host and guardian, will see to it that no harm befalls him, but in his own person and in his own right he has no standing before the law."2

At a later stage in the evolution of Rome, the peregrinus or foreigner,

${ }^{1}$ Based upon an address delivered at Seattle, Wash., before a joint meeting of the Washington, Oregon, Idaho and British Columbia Bar Associations in August, 1917. The germ of the idea here discussed is due to an address by Professor A. V. Dicey at Cambridge University on February 26, 1897, on a Proposal for the Common Citizenship of both Branches of the English People. A brief summary of the address may be found in (1897) 64 NEW YoRK NATion, 198. See also 8 John Adams, Works, 136; 3 John Quincy Adams, Memoirs, 513; Franklin, The Legislative History of Naturalization in the United States, 8-12.

'Salmond, Citizenship and Allegiance (IgOI) I7 LAw QUARr. Rev. 276; Sohm, Institutes of Roman Law (3d ed. translated by Ledlie) I73. 
if he was a member of a state bound to Rome by treaties of friendship, received protection. The praetor peregrinus was established by the side of the praetor urbanus to hear the complaints of such foreigners, and to determine their causes according to the laws of their own states. But such persons were not entitled to the privileges conferred by the law of Rome; the jus civile was reserved for Roman citizens alone. And even when with advancing civilization the system of distinct personal laws applying to citizens and aliens was supplemented by the jus gentium, the principles of justice and fair dealing, the possession of the jus civile still remained synonymous with Roman citizenship. In 212 A. D. the Emperor Caracalla conferred Roman citizenship upon all free members of political communities within the empire. The possession of rights and the possession of citizenship were thus conferred upon all free men within the civilized world. But in legal theory, rights still depended upon citizenship as truly as in the earliest stages of Rome's development, and the barbarian or the person deprived of citizenship as a punishment for crime or otherwise had no rights except so far as they were recognized under the jus gentium. ${ }^{3}$

It would be an interesting study to trace the evolution of the principle of citizenship through the period that followed the fall of the Roman Empire up to the present time. It is sufficient for the purpose of this article to point out that feudalism brought a new principle into the law of citizenship. The theory of a law which in its essence was tribal gave way to the principle which determined one's legal status by one's allegiance.4

In the earlier stages of the development, as Maitland says, "the law of feudal contract attempts for a while to swallow up all other law." The law of the lord's court governed the vassal, save in so far as the law of the universal church controlled him in some of his most important relations. Even to the present day, the English law of citizenship bears marks of its feudal origin; it knows no "citizens." The technical designation of persons born within the king's allegiance is "British subjects." There was probably a time in the development of feudalism when a man's descent and when the place of his birth

\footnotetext{
${ }^{3}$ Sohm, op. cit., I76; Leonhard, Institutionen des römischen Rechts, r88-I89. Traces of its origin still are apparent in the law of citizenship of some of the modern nations whose legal systems are based on the law of Rome. Thus, Austria, Civil Code $\S 28$ : "The full enjoyment of civil rights is acquired by virtue of citizenship"; France, Civil Code, Arts. 8 and Ir. Under the French law, to enjoy political rights one must be a French citizen; to enjoy civil rights, he must be French. Baudry-Lacantinerie, Précis de droit civil (3d ed. I9I4) 902 et seq. On the rights of aliens in France, see Professor Antoine Pillet's article, Some Observations on the Private International Law of the Future (I9I7) 26 YaIE LAW JouRnax, 631, 635-636.

- Salmond, Citizenship and Allegiance (rgor) I7 LAW QUART. Rev. 270; (Ig02) I8 LAW QUART. REv. 49.
} 
were neither of them very significant, the essential question being, to what lord did he owe homage? But by the end of the thirteenth century-the time when the fundamental principles of the common law of England had been outlined-the territorial element at the base of the feudal system has triumphed, though feudalism itself has decayed. Those born in England or in territory subject to the English king are subjects of the English king; those born elsewhere are aliens, excepting those who were children of English subjects within the king's allegiance. The law has thus shifted from the tribal basis to the territorial.s But though the foundations have changed, the alien is still in a sense regarded as a person without rights, and Littleton at the end of the fifteenth century tells us that he can bring no action. ${ }^{\circ}$

The modern conception of citizenship, while it retains traces both of the ancient personal theory and of the medieval feudal theory, has undergone a profound change. In the United States and England, for example, the possession of civil rights does not rest upon citizenship as in Rome, or in the barbarian kingdoms founded upon the wreck of Rome, nor does it rest upon allegiance as in the feudal state. It is to-day in our legal system the rare exception when one's citizenship or allegiance have anything to do with his civil rights. And the exceptions are becoming rarer every day. Such aberrations as are afforded by the alien land legislation of some of our states do not diminish the force of the assertion that citizenship has little to do with the possession of rights. A statute which forbids the acquisition of land by one who is disqualified by federal laws from becoming a citizen has plainly a very limited orbit. In general, it may be said that the British and American theory is that the laws of a state bind all who are within it whether citizens or aliens, and that they do not in general bind its own citizens who are absent from the state. Incapacities arising from alienage have for the most part been removed either by statute or by treaty. Any person, whether citizen or alien, resident or non-resident, is entitled to invoke the law for the protection of his rights. ${ }^{7}$

Our federal Constitution well illustrates the diminished importance which the American system attributes to citizenship and the increased importance which it attributes to the individual. Nowhere in that instrument as it was drafted and adopted in $x 787$ was there any defini-

${ }^{5}$ I Pollock and Maitland, Hist. Eng. Law, 458-467.

- Co. Litt. § 198.

"An alien, which is born out of the ligeance of our soveraigne lord the king, if such alien will sue an action reall or personal, the tenant or defendant may say, that he was borne in such a country, which is out of the king's allegeance, and aske judgment if he shall be answered."

On the various statutes passed during the fifteenth century for the protection of alien friends, see 2 Holdsworth, Hist. Eng. Law, 392-394.

"Beale, Treatise on Conflict of Laws (rg16) $\$ \S 55-57$. 
tion of citizenship, though both citizenship in the United States and in the states are referred to. ${ }^{8}$ It is significant that the first ten amendments proposed in 1789 reiterate the importance of the individual. Rights not granted are reserved to the "people," not to the "citizens" of the states or of the United States; the rights of the "people" to bear arms, to assemble for redress of grievances, to petition the government, to be secure from unreasonable searches, are guaranteed. ${ }^{8}$ The Fourteenth Amendment in I868 for the first time puts a limitation upon the power of the states to deny citizenship to persons born in the state, but it does not itself contain a complete definition of citizenship. All persons born or naturalized in the United States are citizens of the United States and of the state wherein they reside, but under the language of this amendment it would seem to be competent for a state to consider other persons citizens. The most important provisions of the amendment guarantee "persons" against deprivation of life, liberty and property without due process of law, and guarantee to "persons" within the jurisdiction of the states the equal protection of the laws. ${ }^{10}$

American citizenship as such does not even confer ordinary political rights as distinguished from civil rights. A citizen of the United States by virtue merely of his citizenship has no more right to vote than an alien. That right comes wholly from local law. Even the selection of the franchise qualifications in the case of those voting for presidential electors and members of Congress is left to the states. ${ }^{11}$ The only provisions of our federal laws and Constitution upon this subject have to do with a state's forbidding a citizen of 'the United States to vote on account of race, color, or previous conditions of servitude, and with the reduction in representation by reason of denying citizens the right to vote. ${ }^{22}$ The right to vote has been conferred by many of the states upon persons not citizens of the United States. ${ }^{13}$

\footnotetext{
${ }^{8}$ E. g. Art. III, sec. 2; Art. IV, sec. 2. Compare with the silence of our Constitution on the definition of citizenship, Art. 3 of the Constitution of the German Empire of 1871. Annuaire de législation étrangère, 1871, 236-237.

-Amendments to the Constitution of the United States, Arts. I, II, IV and V. See the admirable article on The American Philosophy of Government and its Effect on International Relations by Alpheus Henry Snow, 8 AM. Jour. INT. LAw, I9I-212, particularly at pages r93 et seq. Mr. Snow points out that the American constitutional theory under which rights are not "granted" but only "declared" by constitutions and laws, (Logan v. United States (I892) I44 U. S. 263,293 ) has been transferred to the field of international relations.

${ }^{30}$ The provision that "no State shall make or enforce any law which shall abridge the privileges or immunities of citizens of the United States" has been less often invoked and has a less important effect than either of the other two clauses of the second sentence of section I of the Fourteenth Amendment.

"Art. II, \& I.

${ }^{12}$ Art. XIV, § 2, and Art. XV, § I, Amendments.

${ }^{13}$ Constitution of Delaware, Art. V, $\S 2$; Massachusetts, Art. II, $\S$ I and 2,
} 
The civil rights incident to the condition of American citizenship are equally tenuous. Aside from certain restrictions in the Revised Statutes of the United States upon aliens acquiring claims under the mining laws, and upon their ownership of American vessels, there is scarcely any difference in the legal status under federal laws of citizens and resident aliens. ${ }^{14}$ The former of the restrictions, that in respect to ownership of mineral lands, is so construed by the courts as to render it practically unimportant. No one but the government can question the alien's right to the claim, and even the government can not do so after he has made an assignment to a qualified person. ${ }^{15}$ And the ownership of shipping may be held by a corporation whose stock is controlled by aliens. American citizenship, therefore, as distinguished from state citizenship, means very little indeed so far as concerns the enjoyment of rights and privileges in time of peace.

State citizenship in one of the states of our Union is of even less importance as an independent legal conception than citizenship in the United States. Indeed, a condition that can be put on or off as easily as a suit of clothes may be said to be characterized with too high sounding an expression when it is called citizenship. A citizen of the United States by merely changing his domicile from one state to another is said to change his state citizenship. ${ }^{16}$ If he changes it to a foreign country, he loses his state citizenship, though he remains a citizen of the United States. ${ }^{17}$ Truly, state citizenship is but another phrase for domicile. The latter conception is one fraught with important legal consequences, but it is wholly independent of citizenship.

In time of war, and generally with respect to military duties, citizenship is a matter of great importance. The state demands military service only from its citizens. But in determining questions of enemy character and neutrality, the question of citizenship is by no means controlling. An American citizen living in Germany is an alien enemy so far as concerns his right to sue in an American court, or to make contracts with Americans living in the United States. His goods are subject to seizure as enemy prize upon the seas. Reprisals may be made against his property. On the other hand, the German citizen living in the United States is entitled to all the civil rights and privileges

and Art. III, Amendments; Michigan, Art. 7, $\S$; New Hampshire, Art II, $\S \S$ I2 and 27; New York, Art. II, § I; Pennsylvania, Art. VIII, § I and West Virginia, Art. IV, § I; Stimson, Federal and State Constitutions (Ig08) § 240; I Willoughby, The Constitutional Law of the United States (I9I0) pp. 272-273.

${ }^{11} U$. S. Rev. Stat. $\$ \$ 23 I 9$ and $4 \mathrm{I} 3 \mathrm{I}$.

${ }^{15}$ Manuel v. Wulf (I894) I52 U. S. 505.

${ }^{10}$ See, e. g., Political Code of California, § 5I.

"The citizens of the state are: I. All persons born in this state and residing within it, except the children of transient aliens and of alien public ministers and consuls; 2. All persons born out of this state who are citizens of the United States and residing within this state."

${ }^{17}$ Picquet v. Swan (I83I, C. C. Ist) 5 Mason, 35. 
which belong to citizens, though in the interests of public safety he may be subjected to certain restraints in regard to his power of free locomotion. His property is not enemy property; his contracts are legal; he may sue in our courts as freely as a citizen of the United States. ${ }^{18}$ Neutral character, too, is determined, not by allegiance or citizenship, but by the fact of residence within the neutral state.19 Sometimes language is strangely interpreted to conform with the general principle that all within the state are subject to its laws. For example, treason is defined by Section 533I of the U. S. Revised Statutes thus:

"Every person owing allegiance to the United States who levies war against them, or adheres to their enemies, giving them aid and comfort within the UJnited States or elsewhere, is guilty of treason."

The phrase "person owing allegiance" includes an alien of enemy nationality living in the United States. ${ }^{20}$

If American citizenship is thus attenuated, British citizenship is equally so. The alien may not own shipping registered under the British flag; ${ }^{21}$ he may not make a claim against the Crown;22 he may not sue in a consular court in a place where Great Britain has extraterritorial privileges; ${ }^{23}$ he may not be married under the Foreign Marriage Act in an embassy at Paris or Rome.24 On the other hand, he is free from some disadvantages which follow the British subject abroad. $\mathrm{He}$ is not mentioned in the Treason Act of Henry VIII and presumably

${ }^{13}$ Oppenheim, International Law (2d ed.) IIO-I12, 133-I35; Porter v. Freudenberg [19I5] I K. B. 857. The National Conscription Act of May 18, 1917, subjects to draft aliens, not of enemy character, who have declared their intention to become citizens.

${ }^{19}$ It is inaccurate to speak of neutrality in connection with subjects, though the word is sometimes so used, as in Art. I6 of Convention V of the Second Peace Conference. The character, of course, is one belonging to states. But to determine whether or not the subjects of a given state are to be treated as the subjects of a neutral state, the test is as stated in the text. Thus, subjects of neutral states living in Germany or even in the parts of Belgium occupied by Germany bear a certain degree of enemy character. Oppenheim, 365; Mitsui \& Co. Ltd. v. Mumford [19r5] 2 K. B. 27.

A full comment on The Right of Alien Enemies to Sue in Our Courts is to be found in the November, IgI7, issue of the YAIE LAw JouRnal, p. I04. The various Trading with the Enemy Acts in England and the United States have materially changed the common-law definition of enemy.

${ }^{20}$ Carlisle and Henderson's Case (1873, U. S.) $8 \mathrm{Ct}$ Cl. 153 ; sub nom. Carlisle v. U. S. I6 Wall. 147. So also in England: De Jager v. Attorney General of Natal [1907] A. C. 326. See articles by Samuel MacClintock on Aliens under the Federal Laws of the United States (Igog) 3 ILL. L. REv. 493 and 565; 4 Idem. 27 and 95. [See also Charles Warren, What is Giving Aid and Comfort to the Enemy? p. 33I, post.-Ed.]

${ }^{21}$ Merchant Shipping Act (I894) 57 \& 58 Vict. c. 60, \& I ; 26 Halsbury, 16.

${ }^{22}$ Salmond, Citizenship and Allegiance (I902) I8 LAW QUART. REv. 49, 59-60.

${ }^{23}$ (1890) 53 \& 54 Vict. c. 37.

${ }^{24}$ (1892) $55 \& 56$ Vict. c. 23. 
is not punishable where an act charged to be treason is committed abroad;25 he is not punishable in England for murder, manslaughter or bigamy committed abroad ${ }^{26}$ he is not liable as are British subjects for certain offenses under the Merchant Shipping Act of I894 and under the Explosive Substances Act. ${ }^{27}$ So far as concerns the civil and criminal law, the advantages and disadvantages of British citizenship are about equal.

The jus honorum, the right to be elected and appointed to places of honor, is reserved to British subjects. There was until I9I5 some doubt by reason of unfortunately phrased statutes whether one who was not a natural born subject could hold the office of a Privy Councillor. But the cases of Rex v. Speyer and Rex v. Cassel solved the doubt in favor of the right. ${ }^{28}$ In general, the mother country is by no means jealous with regard to the political privileges attaching to citizens. All political privileges are extended without discrimination to persons born within the king's dominions and allegiance and to persons naturalized in the United Kingdom or in any British possession according to its laws. ${ }^{29}$ There is no office or honor to which a native born Canadian or an alien naturalized according to the law of Canada may not aspire, not only in the British Empire but in the government of England itself. He may represent an English borough in Parliament, though he has never resided in England; he may be a member of the Cabinet, a Lord Chancellor, a Prime Minister.

The conception connoted by the expression "British subject," even more than that covered by American citizenship, fails to fit in with any mechanical theory of sovereignty or of the State. Theoretically it might be said, of course, that the Imperial Parliament, elected by the voters of England, Ireland, Scotland and Wales might repeal the British North America Act and put the government of Canada entirely in the hands of the House of Commons and House of Lords at Westminster or in any other body that it pleased. But such an event is unthinkable. The material tie that has linked the colonies to the mother country has been of the slenderest sort. The Canadian or the New Zealander or the Australian has not even been bound to the empire by the duties that are personified by the tax collector and the drill sergeant. He has neither had to pay taxes nor to come to the defense of the empire when her very life is threatened. And yet how

${ }^{25}$ (I543) 35 Henry VIII, c. 2; Rex v. Casement [r9I7] I K. B. 98, L. J. 467; Report of Interdepartmental Committee on Naturalization. Parliamentary Papers, I90I, Cd. 723, reprinted in Report of American Citizenship Board, H. R. Doc. 326, 59th Congress, 2d session.

${ }^{28}$ (I86I) 24 \& 25 Vict. c. I00, § 9.

${ }^{27}$ Merchant Shipping Act, 57 \& 58 Vict. c. 60; Explosive Substances Act, (1883) $46 \& 47$ Vict. c. $3 \S 3$.

${ }^{28}$ [I9I6] I K. B. 595 .

$=$ British Nationality and Status of Aliens Act (Igr4) 4 \& 5. Geo. V, c. I7. 
absurd is the language which Goldwin Smith used in I888, in view of the events of the past three years!

"What interests," said he, "of the class with which a federal parliament would deal have Australia and Canada in common? What enemy has either of them when the other would be inclined to fight?"30

The British Empire is a perpetual contradiction to the theory of sovereignty on which our jurists and statesmen have been nourished. An "empire" that does not command, "subjects" who are not bound to obey,-small wonder that the Germans denied that there was any reality corresponding to the phrases, British Empire and British subjects. And British nationality is just as hard to fit into the traditional definition as is British citizenship. The languages, the religions, the laws, the institutions of the various peoples making up the British Empire are as various as the colors of their skins. ${ }^{31}$ Yet the British Empire and British nationality are very real things.

The ease with which citizenship may nowadays be put on or off both in the United States and in the British Empire is another indication of the weakening of the traditional relation between sovereign and subject. No law, to be sure, has gone to the extent of the French Revolutionary Constitution of I793 which wholly abolished the oath of allegiance and made citizens of all persons domiciled in France for one year, who lived by labor. ${ }^{32}$ But our own naturalization law passed at the first Congress in I790, while it required the oath of allegiance, required only two years as a basis for citizenship. ${ }^{33}$ In I795 this period of residence was extended to five years, because of the fear that injury might result to republican institutions through the French émigrés. ${ }^{34}$ Those who were residents of the United States when these acts were passed were entitled to naturalization upon proof of two years residence. During the ascendancy of the Federalist party in I798, an act was passed requiring fourteen years residence as a condition of naturalization, ${ }^{35}$ but in 1802 Congress restored the five-year period, $^{36}$ which, in spite of the subsequent assaults of the KnowNothing and American parties has remained stationary ever since. ${ }^{37}$

Liberality toward the naturalization of foreigners has always been

\footnotetext{
${ }^{30}$ Macmmlan's Mag. August, 1888. Cf. Frederick Scott Oliver, Alexander Hamilton (Ig12): "The British Empire is not a political fact, but only a phrase, an influence or a sentiment."

${ }^{81}$ Pollard, Factors in Modern History, r4-17.

${ }^{32}$ Morse, Citizenship by Birth and Naturalization, 323 .

${ }^{23} 2$ Laws of the U.S. from the $4^{\text {th }}$ of March, I789, to the $4^{\text {th }}$ of March, 18I5, $82-83$; I U. S. Stats. at Large, I03.

${ }^{34} 2$ Lawes of the U. S. $466, I$ U. S. Stats. at Large, 414

${ }^{35} 3$ Laws of the U. S. 6I, I U. S. Stats. at Large, 566.

${ }^{36} 3$ Laws of the U. S. 475, 2 U. S. Stats. at Large, I53. 300.

Franklin, The Legislative History of Naturalization in the United States, 184-
} 
a prevailing American tradition. One of our grievances in the Declaration of Independence was that the king

"has endeavoured to prevent the population of these States; for that purpose obstructing the Laws for Naturalization of Foreigners."

In accordance with this liberal spirit, the Act of I790 introduced a radical innovation in the procedure for naturalization by authorizing any court of record to grant the privilege upon proof of the facts. The English law at the time of our Revolution and until r844 knew only one avenue whereby an alien could be naturalized, namely, a special act of Parliament. When one considers the difficulty and expense of securing the passage of a private bill, this requirement made naturalization practically prohibitive. Blackstone, in the edition of his Commentaries published in 1788 , thus states the law upon the subject: $:^{38}$

"Naturalization cannot be performed but by act of parliament: for by this an alien is put in exactly the same state as if he had been born in the king's ligeance; except only that he is incapable, as well as a denizen, of being a member of the privy council, or parliament, holding offices, grants, etc. No bill for naturalization can be received in either house of parliament, without such disabling clause in it: nor without a clause disabling the person from obtaining any immunity in trade thereby, in any foreign country, unless he shall have resided in Britain for seven years next after the commencement of the session in which he is naturalized. Neither can any person be naturalized or restored in blood, unless he hath received the sacrament of the Lord's supper within one month before the bringing in of the bill; and unless he also takes the oaths of allegiance and supremacy in the presence of the parliament. But these provisions have been usually dispensed with by special acts of parliament, previous to bills of naturalization of any foreign princes or princesses."

American ideas have completely conquered the mother country, and it is hardly necessary to point out that the British law of naturalization is to-day as liberal as our own.9 The state is no longer regarded as a sort of guild which exists only for those who are so fortunate as to have been born in a certain place or of parents possessing certain privileges.

\footnotetext{
I Bl. Com. 374.

$\approx$ The first general statute in England which permitted naturalization, by certificate of the Secretary of State, was passed in 1844 (7 \& 8 Vict. c. 66.) The doctrine of "indissoluble allegiance" was abandoned in the Act of 1870 . (33 Vict. c. I4); the remaining trace of the doctrine of descent of citizenship beyond the immediate children of British subjects was abandoned in I9r4 by a statute prepared before the war. (4\&5 Geo. V, c. I7.) This last statute permits each of the Dominions to confer British citizenship, if they choose to do so. The act may be adopted or not by the Dominions and they may rescind it whenever they please. This is the high-water mark of liberality in conferring citizenship.
} 
Mr. Salmond thus sums up the situation:

"The acquisition and loss of citizenship are being gradually made easier, while the legal effects of such acquisition and loss are gradually being made less. The present state of things is indeed a compromise between two fundamentally different ideas as to the constitution of a political society. Citizenship and its remaining privileges are the outcome of the primitive conception of the state as a personal and permanent union of determinate individuals, for whose exclusive benefit the laws and government of the state exist. Residence, regarded as a title of membership and protection, is the product of the more modern conception of the state as consisting merely of the inhabitants for the time being of a certain territory. The personal idea is gradually giving place to the territorial." 40

In passing it may be noticed that the contrast between the personal and the territorial idea does not exhaust the matter. The laws under our system exist as well for persons who have never been in the state as for citizens or 'inhabitants. The state does not, in general, inquire whether one claiming a right under its laws is or is not a resident any more than it inquires whether he is a citizen. The question of residence or domicile does, indeed, become important in questions of status and succession. But as a general principle the idea of domicile itself is, like that of citizenship, one of diminishing importance in the determination of rights. The territorial theory of law is gaining ground both in England and America.

Equally significant with respect to the increased importance attributed to the individual and the modification of the idea of allegiance have been the changes in the law regarding expatriation, especially in the United States and in England. In .I8I7, Jefferson in a letter to a friend said:

"My opinion on the right of expatriation has been so long ago as the year 1776 consigned to record in the Act of the Virginia Code drawn by myself recognizing the right expressly and prescribing the mode of exercising it. The evidence of this natural right like that of the right to life, liberty and the use of our faculties, the pursuit of happiness, is not left to the feeble and sophistical investigations of the reason but is impressed on the sense of every man. We do not claim these under the charters of Kings or legislators, but under the King of Kings." 41

Notwithstanding Jefferson's views and those of political thinkers of the school to which he belonged, it was not until I868 that Congress wrote into our laws the following provision in language that recalls Jefferson:

"Whereas the right of expatriation is a natural and inherent right of all people, indispensable to the enjoyment of the rights of life,

to Salmond, Jurisp. I95.

a Io Jefferson, Writings, 87. 
liberty and the pursuit of happiness; and whereas in the recognition of this principle this Government has freely received emigrants from all nations, and invested them with the rights of citizenship; and whereas it is claimed that such American citizens, with their descendants, are subjects of foreign states, owing allegiance to the Government thereof; and whereas it is necessary to the maintenance of public peace that this claim of foreign allegiance should be promptly and finally disavowed: Therefore any declaration, instruction, opinion, order, or decision of any officer of the United States which denies, restricts, impairs, or questions the right of expatriation, is declared inconsistent with the fundamental principles of the Republic."42

The status of a British subject under Section I3 of the British Nationality and Status of Aliens Act, I9I4, provides that a British subject by obtaining a certificate of naturalization or otherwise becoming naturalized in a foreign country ceases to be a British subject. ${ }^{43}$

The right of expatriation, and, indeed, the entire law of naturalization, has been much extended by conventions entered into between the United States and other powers. One of the first of these was that negotiated through the offices of George Bancroft, Minister at Berlin, with the North German Confederation in I868.4 This convention, which is the model of subsequent treaties on the same subject, provides for the reciprocal recognition of naturalization in either by the other of the contracting powers. The ratification of the convention was followed immediately by the Act of Congress of July I7, I868, recognizing the right of expatriation, and that act in turn was followed by the adoption of the British act to the same effect in 1870.45 The recommendations of the commission appointed to report to Congress in 1906 upon the subject of naturalization, consisting of Messrs. James Brown Scott, David Jayne Hill and Gaillard Hunt, were strongly in favor of extending the number of these conventions. Comparatively few new naturalization treaties have been negotiated since that date, but the fact that since 1868 a large number of such conventions have been made has done much to increase the scope of the principle of expatriation. ${ }^{46}$

The diminishing importance of the principle of descent in determining citizenship is another evidence of the loosening tie which the state holds over the individual. In Roman law and in the continental nations of Europe, the question of citizenship has always been determined by descent. The governing principle of nationality-under the French

"U. S. Rev. Stat, Sec. 1999. Cf. (I870) 33 Vict. c. 14

- (IgI4) 4 \& 5 Geo. V. c. I7.

" 2 Malloy, Treaties, Conventions, etc., between the U. S. and Other Powers (I910) 1298.

Supra, n. 42.

"See Report of American Citizenship Board (1906) H. R. Doc. 326, 59th Congress, 2d Session; Borchard, The Diplomatic Protection of Citizens Abroad (1915) $544-552,674-687$. 
law, for example-is the jus sanguinis. A child of American parents, born in Paris, was until I889 not French, nor were his grandchildren or his descendants to the remotest generation French, so long as they remained unnaturalized; e converso the descendants of French people living in foreign countries retained and still retain their French nationality. ${ }^{47}$ On the other hand, the English law from which our law of citizenship is derived determines citizenship by the place of birth. The child of Chinese parentage, born in a British colony or in the United States, is a British or American citizen, even though he belongs to a race excluded from the benefit of the naturalization laws. ${ }^{48}$ It is very plain that the English and the American rule which determines citizenship by the principle of place of birth, the jus soli, rather than by that of descent, the jus sanguinis, operates in favor of diminishing the importance of the idea that citizenship is an unchangeable status, and makes for mobility in respect to the individual. English law from I350 to I9I4, however, retained so much of the principle of jus sanguinis as to recognize, in the case of persons of English or British blood born abroad, their British nationality to the third generation. The United States at the beginning of her legislation abandoned the English rule, and confines the privileges of American citizenship to children of Americans born abroad; the right of citizenship has never descended to the grandchildren of American citizens who may happen to be born abroad, unless their parents have resided in the United States. In IgI4 the British Parliament adopted the American view and abandoned the principle of English law maintained for more than five centuries which permitted grandchildren of English subjects born abroad to retain their British citizenship. ${ }^{49}$ The Latin-American countries, too, though their legal systems are based upon the civil law, indicate a very distinct tendency toward the adoption of the doctrine of jus soli, or at least toward a minimization of the principle of jus sanguinis. The Constitution of Brazil, for example, permits children of Brazilian parents born abroad to claim Brazilian citizenship, provided they become domiciled in Brazil. It recognizes the principle of jus sanguinis, therefore, to a much less degree than France or Italy, which do not mention domicile. It is said that at least fourteen states of Latin America claim as nationals all born within their territory.

While it must be conceded that the law of continental Europe still clings to the principle of descent or blood as the test of citizenship, it is also true that some inroads have been made upon that principle

"Baudry-Lacantinerie, Précis de droit civil (I9I4) 902-918; (IgI5) 9 AM. JoUR. INT. LAW, 942.

${ }^{4} U$. S. v. Wong Kim Ark (1898) r69 U. S. 649.

$\checkmark$ This recommendation was made by the Interdepartmental Committee on the subject of naturalization in its Report to Parliament of July 24, I90I. See H. R. Doc. 326 , 59th Cong., $2 d$ Sess., at p. 346, where this report is reprinted. 
in favor of the doctrine of jus soli. France, until 1889 , held that a person born on French soil of foreign parents followed the nationality of his parents, but in that year a law was passed whereby such person, if he remains domiciled in France until majority, is French, unless he disclaims French nationality within the year following his reaching majority. He cannot disclaim, however, if he has not performed military service as required by the country of his parent's nationality. Since I893, every person born in France, one of whose parents is French, is also French, subject to the right to disclaim as provided in the law of 1889 . The provisions of the law of I889 may be modified by treaty. The French Civil Code permits expatriation, but insists on the consent of the French government where the party seeking naturalization abroad is liable to military duties. France, however, still insists that children and grandchildren of French parents born abroad remain French. ${ }^{\text {so }}$

Italy, whose jurists and legislators are deeply impregnated with theories of nationality, has, like France, adopted in a modified form the principle of $j u s$ soli, in her more recent legislation. Article III of the Law of June I3, I9I2, accords to persons born in Italy the privileges of Italian citizenship, somewhat as under the French law of I889. Conversely it is provided by Article VII of this law-and in this respect Italy has gone beyond France-that persons of Italian parentage born and residing abroad, may, at majority, renounce their Italian nationality, if their place of birth claims them as citizens. Treaties may modify these provisions. The Italian law also recognizes expatriation under Article VIII, but the acquisition of a new nationality does not absolve the person acquiring it from his Italian military obligations. In presenting this legislation the government declared its purpose to avoid conflicts between the various laws of nationality, giving rise to perplexing questions of "dual nationality." The government desired to make the law of nationality conform

"with the actual exigencies of social life, in particular those which result from the great currents of emigration and from the facility with which citizens of divers nationalities are detached from their countries of birth."

The law as passed indicates a broader spirit of comity and a greater willingness to leave to the individual choice with reference to the selection of his nationality than has been the case in former Italian legislation on this subject. The modification of the principle of indissoluble allegiance in a country whose legal thinkers have stood in the front rank as champions of the principle of nationality, is significant of the changing conception of the relation of the individual to the state..$^{\text {s1 }}$

${ }^{30}$ Civil Code, Art. 8, \& 5, added by the Law of June 26, $x 889$.

"On "dual citizenship" see 3 Moore, Digest of International Law (Ig06) 
Of the great western nations, Germany alone has during the last half-century tended to show in her legislation upon citizenship a retrogressive tendency. The law of the German Empire of I87I in respect to nationality, which was adopted from the North German Confederation, was indeed framed on liberal lines. It expressly declared, for example, that adoption cannot affect the nationality of the person adopted; it recognized the right of expatriation by a provision that a citizen lost his nationality by ten years residence abroad, and it authorized this period to be reduced to five years by treaties with foreign countries. ${ }^{52}$ But in January, I9I4, six months before the war, a new nationality law was adopted for the empire. The spirit of this law indicates something of a return to the tribal theory of citizenship. Loss of German citizenship no longer follows upon absence in a foreign country as was the case under the law of $I 87 \mathrm{I}$, nor is there any provision for naturalization treaties. Some of the provisions of the new law show an extreme disregard for the legislation and internal policy of other countries. Thus, a former German or a descendant of a former German may secure naturalization in Germany without ever living there or leaving the country of which he is a citizen, and this rule even applies to the adopted children of Germans. As Germany, like France, adopts the principle of jus sanguinis, this can only mean that the children, natural or adoptive, the grandchildren and descendants to the remotest generation of those who were once German but have ceased to be such by naturalization or other act, can, without leaving the country to which they owe allegiance, even if it is the country of their birth and parentage, become citizens of the German Empire. $^{53}$ No modern state before this law had permitted naturalization to persons who have never been in the country, though the French National Assembly did by special act confer French citizenship upon some distinguished individuals, among others, Jeremy Bentham, Thomas Paine and George Washington. The conferring of citizenship in such a way, however, could hardly be said to interfere with the internal policy of other states as does the German Act of I9I4. The

5I8 et seq., and Borchard, The Diplomatic Protection of Citizens Abroad (I9I5) 580 et seq. On the French law, see Baudry-Lacantinerie, Précis de droit civil (3d ed. 19I4) g02 et seq. For the Italian law of I9I2, see Annuaire de législation étrangère (I9I2) I47. The law of the Latin-American states is discussed by Harmodis Arias, Nationality and Naturalisation in Latin America from the Point of View of International Law (I9Io) II Jour. Soc. CoMp. LFG. (N. S.) I26. The English law of rgI4 may be found in (Igr5) 9 AM. Jour. INT. LAw, Supp. 4I3, and an article on the same by Richard W. Flournoy, Jr.; The New British Imperial Law of Nationality, 9 Ibid. 870.

${ }^{52}$ Annuaire de législation étrangère ( $187 \mathrm{y}$ ) 183 , contains a French translation of the text of the Reichsgesetz of June I, 1870 .

The full text of the law in English translation may be found in (ror4) 8 AM. Jour. INT. LAW, Supp. 2r7-227. It is commented upon in the same Journal, vol. 8, 477 by Richard W. Flournoy, Jr., and also in vol. 9, 939. 
twenty-fifth section of the new Nationality Act contains this remarkable provision:

"Citizenship is not lost by one who, before acquiring foreign citizenship, has secured upon application the written consent of the competent authorities of his home state to retain his citizenship."

While elsewhere the claims of blood descent have been weakening, Germany proclaims that those of German blood may demand German citizenship, though there be no territorial relation between them and the state. It might be noted that a German seeking naturalization in the United States and attempting to take advantage of section 25 of the German Act would have to commit perjury, for he must by our laws forswear his former allegiance. ${ }^{54}$

\footnotetext{
st The Emperor of Germany in opening the Reichstag on February 7, r9r2,
} stated the object of the law to be to preserve to Germans residing abroad their nationality to the farthest degree possible and to permit them to recover it when they have lost it. Annuaire de législation étrangère (1912) 29: "Il a amoncé le depôt d'un projet de loi ayant pour objet de conserver le plus possible leur nationalité aux Allemands résidant d̀ l'étranger et de leur permettre de la recouvrer quand ils lont perdue; c'est encore un moyen de fortifier l'influence germanique hors des frontières."

Professor Borchard has kindly called the writer's attention to the fact that the clause of the German law permitting the retention of German citizenship was designed, as the committee reports of the Reichstag show, to preserve German citizenship for such Germans as become nationals of other countries without their demanding such new nationality, as is the case where one marries a Brazilian woman, or for merely economic reasons, as to enable them to practice certain professions or to own real estate in certain South American countries. The language of the statute, of which the writer unfortunately has been able only to procure the English and French translations, is certainly sufficiently broad to justify the statement made in the text. The law is certainly not worded with the precision which we might expect from a German statute, if its purpose was only as stated in the Reichstag's committee report. That the Bancroft treaties would probably prevent the application of the law to the United States is immaterial, for the reference was only used for the general purpose of illustrating the fact that the new German law indicates a narrow conception of the principle of nationality, and a disregard of the internal policy of other states.

Professor Borchard also suggests that a German applying for naturalization in the United States would no more be guilty of perjury than a Frenchman forswearing allegiance to France. The Frenchman, however, may well be honest when he forswears allegiance, though his native law refuses to give his act legal effect. $\mathrm{He}$ certainly means to forswear allegiance, and hopes that the United States will support his claim of citizenship even as against France. The German, on the other hand, who has expressly claimed his German citizenship in writing can hardly speak the truth when he takes an oath to the effect that he forswears allegiance to the fatherland. The view of the clause stated in the text is also taken by the writer of a comment on the German Nationality Act, 9 AMr. Jour. INT. LAw, 94r.

[An exhaustive article on the question of dual allegiance in relation to the German Nationality Act of I9I3, by Theodore $\mathrm{H}$. Thiesing of the Legislative Reference Division of the Library of Congress, will be published in an early number of the YALE LAW JoURNAL. $-E d$. 
The illustrations in this article pointing out the altered views concerning membership in the state in the great liberal nations of the world, must have suggested the idea that it would not be very revolutionary to extend the analogy of interstate citizenship which now exists among the states of our Union to an international citizenship among the states of the world. A citizenship in a world state would thus be created, not so very unlike that now existing in the British Empire. Indeed, that situation in practice almost exists to-day. Treaties of the United States confer upon the citizens of other countries most of the privileges, other than political, which are possessed by our own citizens. A rather recent treaty with Italy even goes so far as to grant to Italian subjects, whether resident or non-resident, the benefit of local statutes for wrongful death, for the purpose apparently of nullifying an unfortunate line of court decisions. ${ }^{55}$ The most favored nation clause may, in some cases, extend privileges granted to the subjects of one country to other countries. No very radical change would be effected in the civil rights of aliens if what is done indirectly by special treaties were done directly by ordinary legislation. Suppose, for example, that the United States should confer American citizenship upon all British subjects, and that the Imperial Parliament should confer British citizenship upon all Americans. The civil rights of citizens of the United States in England or Canada would scarcely be changed, nor would those of British citizens living in the United States. The most important single change with respect to civil rights would be that each might own interests in the other's shipping, certainly not a very fundamental matter in these days of corporation and international finance.

But, it may be said, inter-citizenship would frightfully upset our political system. An Englishman or a Canadian under such a system might vote to hold office even though he was not permanently attached to our country. It is to be remembered, however, that the right to vote and hold office is not universal among our own citizens. Iocal statutes protect the franchise by varying requirements with reference to length of residence, educational standards, etc. Moreover, the holding of office is dependent upon the power of getting it, and there would be little likelihood of a stranger being elected or appointed to important office. As English law now exists, any British citizen, no matter where he lives, may represent an English borough in Parliament, but the instances where Australians or Canadians have availed themselves of the privilege are rare. It is by no means certain that it would not be desirable to have an occasional foreign representative in our halls of legislation.

With respect to international relations, the innovation would have

${ }^{50} 3$ Charles, Treaties, etc., between the U. S. and Other Powers, 442. (Feb. 25, 1913.) 
more important consequences. Indeed, the main purpose of the alteration in the law would be for its effect upon those relations. The duty of military service should doubtless be limited to those who were actually within the territory of the country demanding the services, and, perhaps, an Englishman born should not be required by the law of the United States to fight against the country of his birth. In dealing with other nations, the sovereignty of each of the states granting common citizenship would be undisturbed. Thus, the United States would be under no greater legal obligation to aid in redressing the violation of Belgium's neutrality than it was in August, I9I4, even though its citizens were also British or French citizens. Perhaps, if a common citizenship had existed, we would have entered the war in I9I4, rather than in I9I7, just as Australia and Canada entered it. But this would not have been because of any legal compulsion, but because of the consciousness of close relations with those who shared citizenship with us. Indeed, if a common citizenship had existed between subjects of the British Empire and citizens of the United States, it may well be doubted whether the attack upon Belgium would have been made. Such a power as that represented by the United States joined with that of the British Empire would be one that could not lightly be defied. The world war has demonstrated how effective such a nondescript political device as British citizenship can be even in terms of military power. The lesson will not soon be lost.

It may be urged by Americans against the notion of common citizenship that it would involve us in the intrigues of European diplomacy. But the United States has never been a party to secret treaties, and her influence will weigh to lessen the possibility of such arrangements in the reconstructed world. While secret diplomacy is more or less of a myth, since the mutual rights and duties of the parties to secret alliances are usually as well known to the public men of those nations against whom the alliances are directed as to those of the contracting parties, democracy demands that the forms of secrecy be abandoned, and that the agents of the people should not be permitted to withhold from the principal their private knowledge. The diplomacy of the present is suitable only to dynastic states, and it should disappear with the dynastic form of government. The force of a public opinion based upon a wider principle of citizenship would have a powerful tendency towards placing the diplomacy of the world on a surer basis. Statesmen, conscious that they are dealing with units bound together by moral ties only, will be obliged to defer to a wider public opinion than has been the case in the past..68

"Hobhouse, Morals in Evolution, 64:

"Every human being, in proportion as he is normally developed, is able to enter into and contribute to the good life so conceived, and that he should do so is the sum and substance of all his duties to society and all the duties of society to him. But this same principle once pushed through, annuls, ethically speaking, 
The plan proposed is not designed to undermine the idea of nationality or to interfere with the virtue of patriotism. Indeed, that virtue is by no means dependent upon the existence of an autonomous state. The Scotchman has never been blamed for a defect of patriotism nor of a keen sense of nationality, nor does the loyalty of the Californian to his native or adopted state interfere in the slightest degree with his loyalty to the United States. On the contrary, the spirit of loyalty has been intensified rather than diminished by the dual spiritual allegiance. Even if it be conceded that the consciousness of citizenship in other national units would at first produce but a faint glow in the heart of the American citizen, it is nevertheless one that might be warmed to flame. He might come in time to think in terms of humanity rather than of nationality, to prize the possession of common ideals and aspirations rather than the accident of place of birth or descent, to regard himself as a citizen of a world state rather than the fortunate inheritor of a special and superior civilization.

President Wilson in an address delivered on September 8, 1916, before the National American Suffrage Association pointed out that the older theories of government were fundamentally based upon the mechanistic idea of the universe to which Newton gave voice. We know that in our own country the attempt to control the development of our life by mechanistic formulas has failed. In the wider field of international relations, it is doubtful whether a league to enforce peace based upon the principle of written compacts and formal understandings is capable of solving the problem of world peace. If there is to be an effective league to enforce peace, it must rest upon an international public opinion. One of the best bases for such a public opinion is the conception of inter-citizenship between the citizens of the great powers.

the distinction between citizen and foreigner, for the foreigner may be quite equally capable of the same life, and, if so is morally seized of the same rights and duties, and if, through difference of race, he is not always equally capable, still his rights and duties cannot fall to zero, but vary only with the degree of his incapacity. Hence the fully developed state in which the principle of personality is vigorously carried through, must also find itself in definite ethical relation to humanity as a whole." 